\title{
MENEPIS PRASANGKA DAN DISKRIMINASI DALAM PERILAKU BERAGAMA UNTUK MASA DEPAN MULTIKULTURALISME DI INDONESIA
}

\author{
Triana Rosalina Noor \\ STAI An Najah Indonesia Mandiri Sidoarjo, INDONESIA \\ Correspondence: $\square$ trianasuprayoga@gmail.com
}

\begin{abstract}
Indonesia is a multicultural nation that has a variety of ethnic, racial, cultural, linguistic, and religious diversity. This diversity makes its challenges in creating a harmonious society. This is because it can bring some people trapped prejudice and discrimination, especially in religion. The prejudice that leads to discrimination and acts of violence will make social conflicts more acute in the multidimensional crises that occur in Indonesia.This article aims to describe prejudice and discrimination behavior from an individual psychological perspective, sociological, and cultural background. Besides that, it was also explained the idea of how to prevent and overcome prejudice and discrimination in religious beliefs that occurred. Efforts to prevent prejudice and discriminatory behavior in religion can be done by increasing the value of the group that is prejudiced, opening communication, conditioning the environment to internalize social norms. The hope is that all citizens can live side by side and respect each other in a peaceful and peaceful atmosphere.
\end{abstract}

\section{Article History}

Received: 10-08-2020,

Revised: 16-12-2020,

Accepted: $31-12-2020$

\section{Keywords:}

Discrimination;

Multicultiralism;

Prejudice;

Religious Behaviour

\section{Histori Artikel}

Diterima: 10-08-2020

Direvisi: $16-12-2020$

Disetujui: 31-12-2020

\section{Kata Kunci:}

Diskriminasi;

Multikulturalisme;

Perilaku Beragama;

Prasangka individu. Selain itu dijelaskan pula gagasan tentang bagaimana mencegah dan mengatasi prasangka buruk dan diskriminasi dalam keyakinan beragama yang terjadi. Penulisan artikel ilmiah ini adalah menggunakan penelitian kepustakaan, peneliti menelaah teori-teori, konsep-konsep, definisi, pengertian tentang variabel-variabel yang diteliti untuk dicari keterkaitannya. Upaya pencegahan prasangka dan perilaku diskriminatif dalam beragama dapat dilakukan dengan meningkatkan nilai kelompok yang berprasangka, membuka komunikasi, mengkondisikan lingkungan hingga menginternalisasi normanorma sosial. Harapannya, semua warga bisa hidup berdampingan dan saling menghormati dalam suasana damai dan damai.

\section{A. Pendahuluan}

Bangsa Indonesia adalah bangsa multikultural yang memiliki berbagai keanekaragaman suku, ras, budaya, bahasa dan agama. Adanya keberagaman telah menjadi tantangan tersendiri dalam 
mewujudkan masyarakat yang harmonis. Multikulturalisme secara sederhana dapat dipahami sebagai sebuah pengakuan bahwa masyarakat memiliki kemajemukan dan berkomitmen untuk mengakui kemajemukan tersebut sebagai ciri utama masyarakat itu sendiri. ${ }^{1}$ Multikulturalisme merupakan konsep dimana sebuah komunitas dalam konteks berbangsa dapat mengakui adanya keberagaman, perbedaan dan kemajemukan budaya, ras, agama dan bahasa. Multikulturalisme menjadi gambaran dari keragaman yang terjadi di tengah masyarakat atau suatu bangsa. Artinya ada suatu semangat untuk dapat dapat hidup berdampingan dan saling menghormati dalam suasana damai dan rukun (co-existence). ${ }^{2}$

Saat ini Indonesia mengakui adanya enam agama yakni Agama Islam, Kristen Protestan, Katolik, Hindu, Buddha dan Kong $\mathrm{Hu} \mathrm{Cu}$. Negara menjamin masing-masing pemeluk agama untuk untuk memeluk agamanya masing-masing dan untuk beribadat menurut agamanya dan kepercayaannya itu sebagaimana tertuang pada UUD 1945 pada pasal 29. Namun ternyata adanya krisis multidimensional yang dihadapi bangsa Indonesia hingga saat ini membuat pemerintah harus melakukan banyak perbaikan untuk bisa menuju sebuah pergerakan yang lebih baik di segala bidang tanpa terkecuali dalam hal keagamaan. Krisis tersebut bahkan membuat sebagian anak bangsa gamang menatap masa depan mereka. Meningkatnya perilaku kekerasan diantara anak bangsa mengakibatkan hilangnya keramahan antar sesama warga. ${ }^{3}$

Sebagai bangsa yang beragama sudah sepatutnya agama yang diyakini oleh masing-masing warga tersebut berfungsi dalam hal sumber pengawasan sosial yang mengikat pemeluknya. Agama juga akan bertanggung jawab atas berlakunya norma-norma yang ada di masyarakat. ${ }^{4}$ Akan tetapi pada kenyataannya masih ada saja terjadi konflik-konflik sosial yang dilatarbelakangi oleh perbedaan ciri-ciri yang dibawa individu dalam berinteraksi seperti perbedaan agama, suku, status ekonomi dan lain sebagainya. Agama ternyata belum sepenuhnya bisa berperan dalam meredam konflik sosial yang terjadi antar sesama. Bahkan sebaliknya konflik sosial tersebut diatasnamakan sebagai bentuk kesucian agama. ${ }^{5}$ Meskipun pada kenyataannya konflik yang terjadi tersebut tidak serta merta merupakan konflik agama. Namun tetap saja kondisi tersebut bisa membangkitkan perasaan tidak aman (insecured), kebencian (hated), dan kemarahan (anger) yang dapat memicu tindakan main hukum sendiri dari penganut agama atas penganut agama lainnya sehingga muncul sentimen keagamaan untuk memecah belah umat beragama dan menghancurkan kerukunan. ${ }^{6}$

Beberapa kasus konflik sosial yang pernah terjadi salah satunya pada tahun 2018, yakni adanya perselisihan antara kaum muslim dan non muslim di Papua. Perselisihan tersebut dipicu oleh ketidaksepakatan pihak gereja atas pembangungan mesjid yang dilakukan oleh umat muslim yang dinilai terlalu tinggi sehingga terlihat mendominasi daripada bangunan lainnya. ${ }^{7}$ Pada tahun 2019, seorang warga beragama Katolik juga tidak diperkenankan tinggal di sebuah desa di Bantul Yogyakarta. Hal ini disebabkan oleh karena yang bersangkutan tidak memeluk agama mayoritas

\footnotetext{
1 Kasinyo Harto, Model Pengembangan Pendidikan Agama Islam Berbasis Multikultural (Jakarta: PT. RajaGrafindo Persada, 2014). 21

${ }^{2}$ Muhammad Tholchah Hasan, Pendidikan Multikultural Sebagai Opsi Penanggulangan Radikalisme (Malang: Lembaga Penerbitan Univ. Islam Malang, 2016). 9

${ }^{3}$ Sudarto Sudarto, Wacana Islam Progresif (Yogyakarta: IRCiSod, 2014). 205

${ }^{4}$ Hamzah Tualeka, Sosiologi Agama (Surabaya: IAIN Sunan Ampel Press, 2011). 79

5 Saihu Saihu, "Pendidikan Pluralisme Agama: Kajian tentang Integrasi Budaya dan Agama dalam Menyelesaikan Konflik Sosial Kontemporer,” Jurnal Indo Islamika 9, no. 1 (2019): 67-90.

6 Triana Rosalina Noor, "Meneropong Indonesia: Sebuah Analisis Sosiologis dan Psikologis Atas Konflik Benuansa Keagamaan Di Indonesia,” Journal An-Nafs: Kajian Penelitian Psikologi 3, no. 2 (2018): 135-150.

7 Tiara Sutari, "Selesaikan Konflik Masjid di Papua Lewat Musyawarah," last modified 2018, https://www.cnnindonesia.com/nasional/20180318101351-20-283902/menag-selesaikan-konflik-masjid-di-papualewat-musyawarah.
} 
sebagaimana warga lainnya. Kondisi ini diperparah oleh tindakan tersebut didasarkan pada peraturan desa yang berlaku, yakni tidak mengizinkan warga yang bermukim selain agama mayoritas Islam. ${ }^{8}$ Dan peristiwa yang tak kalah kontroversial juga terjadi di penghujung tahun 2020 ini, yakni sebagian kaum muslimin dikagetkan dengan berita ditangkapnya Habib Rizieq oleh karena ditetapkan sebagai tersangka terjadinya kerumunan di Petamburan, Jakarta. Sebagian pihak mengasumsikan adanya diskriminasi penegakkan hukum yang saat ini masih bersifat tajam ke masyarakat bawah dan tumpul ke petinggi pemerintahan. ${ }^{9}$

Konflik sosial yang terjadi tersebut diantaranya disebabkan oleh adanya prasangka dan diskriminasi dalam interaksi sosial. Brehm dan Kassin berpendapat bahwa prasangka merupakan perasaan negatif yang ditujukan kepada seseorang atau kelompok berdasar semata-mata keanggotaan mereka pada sebuah komunitas tertentu. ${ }^{10}$ Prasangka ini melibatkan sebuah penilaian tertentu yang bersifat subyektif untuk memperlakukan subyek prasangka dengan melekatkan karakteristik komunitas yang menonjol. Artinya seseorang akan memiliki keyakinan bahwa orang lain atau kelompok yang berbeda adalah tergolong salah. Kondisi tersebut bisa termasuk dalam sebuah abnormalitas dalam beragama. Hal ini mengindikasikan bahwa ada ketidakmampuan seseorang untuk menyesuaikan diri dengan institusi agama yang dipeluknya. ${ }^{11}$

Adapun diskriminasi merupakan perilaku yang diarahkan pada seseorang yang didasarkan semata-mata pada keanggotaan kelompok yang dimilikinya. Diskriminasi ini mula-mulanya berawal dari adanya prasangka yang pada awalnya hanya perasaan-perasaan negatif yang lambat laun membawa seseorang pada tindakan-tindakan membedakan terhadap orang-orang yang termasuk golongan lain yang berbeda dari dirinya. Tindakan-tindakan diskriminatif ini diartikan menjadi sebuah tindakan yang bercorak menghambat, merugikan perkembangan bahkan mengancam kehidupan pribadi orang lain yang kebetulan mungkin masuk dalam kelompok yang ia prasangkai. ${ }^{12}$ Diskriminasi meliputi perilaku rasis, suku, agama dan budaya dan jenis kelamin. ${ }^{13}$ Sebagai contoh: seseorang atau kelompok menilai kelompok lain yang berbeda dengan dirinya sebagai kelompok yang "sesat" dan memberi label "kafir". Sebagaimana fenomena takfirisme yang menganggap orang lain yang berbeda pandangan ideologinya akan dipandang sebagai golongan kafir. $^{14}$

Untuk menciptakan tatanan masyarakat Indonesia yang multikultural tentulah tidak mudah. Paling tidak dibutuhkan beberapa kajian konsep yang mendukung demi terwujudnya tatanan multikultural yang betul-betul berpijak pada konsep yang kuat dan tidak mudah terombang-ambing oleh kondisi lingkungan.

\section{B. Metode Penelitian}

Metode penelitian yang digunakan dalam penulisan artikel ilmiah ini adalah menggunakan penelitian kepustakaan. Peneliti menelaah teori-teori, konsep-konsep, definisi, pengertian tentang variabel-variabel yang diteliti untuk dicari keterkaitannya. Peneliti akan mencoba menghubung-

8 "Diusir dari desa karena agama, bagaimana mencegah intoleransi di tingkat warga?," 2018, https://www.bbc.com/indonesia/indonesia-47801818.

9 Harits Tryan Akhmad, "FPI Minta Mahfud MD Bersuara Lantang soal Dugaan Kriminalisasi Ulama dan Diskriminasi Hukum," last modified 2020, https://nasional.sindonews.com/read/250890/13/fpi-minta-mahfud-mdbersuara-lantang-soal-dugaan-kriminalisasi-ulama-dan-diskriminasi-hukum-1606720276.

${ }^{10}$ Tri Dayakisni dan Hudaniah Hudaniah, Psikologi Sosial (Malang: UMM Press, 2012). 199

${ }^{11}$ Ahmad Saifuddin, Psikologi Agama (Jakarta: Kencana, 2020). 213

12 W. A Gerungan, Psikologi Sosial (Bandung: PT. Refika Aditama, 2004). 180

${ }^{13}$ Kenneth S. Bordens dan Irwin A. Horowitz, Social Psychology (USA: Freeload Press, 2008). 112

${ }^{14}$ Sony Amrullah, "Melacak Jejak Radikalisme dalam Islam: Akar Ideologis dan Eksistensinya dari Masa ke Masa," Dirasah: Jurnal Studi Ilmu dan Manajemen Pendidikan Islam 1, no. 2 (2018): 1. 
kaitkan antara konsep-konsep yang ada, mana yang menjadi sebab dan dampak atas sebuah fenomena yang terjadi. ${ }^{15}$

\section{Pembahasan atau Analisis \\ Prasangka Dan Diskriminasi dalam Beragama}

Telah dipahami dan disadari bersama-sama bahwa tidak ada agama yang mengajarkan untuk berprasangka, membedakan, melakukan kekerasan, dan berkonflik antara satu dengan yang lain. Namun tetap saja tidak bisa menutup mata bahwa pada kenyatannya agama sering "dikesankan" dengan hal yang kaku, sehingga keterlibatan agama sebagai pemicu terjadinya konflik pasti akan menimbulkan pertanyaan bagi semua. Agama yang diturunkan ke bumi membawa pesan keTuhanan dan kemanusiaan yang sama. Pesan yang ditekankan pada masing-masing agama adalah terkait pentingnya penciptaan perdamaian berdasarkan prinsip persamaan dan kesatuan manusia. Pesan ini ternyata belum sepenuhnya menjadi rujukan kolektif semua pemeluk agama, karena kompleksitas persoalan historis ataupun sosiologis yang melekat pada semua pemeluk agama. Konflik antar agama dan keyakinan pernah menjadi sisi kelam dan merugikan martabat agama dan kemanusiaan itu sendiri. ${ }^{16}$

Refleksi realitas berdasarkan pengalaman keberagamaan yang terjadi di masyarakat Indonesia dalam beberapa tahun terakhir menunjukkan betapa pemahaman masyarakat Indonesia masih ada yang eksklusif, rigid, anti dialog dan sarat dengan "haus kekuasaan" terhadap yang lain, sehingga muncul lah permasalahan seperti adanya prasangka, diskriminasi ataupun konflik. Selain itu, sebagian orang masih mengenal agama sebagai ajaran yang kaku, ekslusif dan tidak akan berubah sampai kapanpun. ${ }^{17}$

Agama yang seharusnya menjadi perekat sosial ternyata malah terjebak pada tataran konflik. Pada konteks mikro, sebenarnya agama dapat diperankan secara positif konstruktif dalam mempertahankan dan sekaligus mengembangkan keutuhan bangsa Indonesia yang ditandai dengan keanekaragaman dan kemajemukan. ${ }^{18}$

Terjadinya prasangka dan diskriminasi ataupun kekerasan dalam beragama atau bisa dikatakan sebagai sebuah abnormalitas dalam agama adalah sebuah bentuk penyakit hati yang dapat mengganggu realisasi dan aktualisasi diri seseorang. Mujib ${ }^{19}$ telah mengklasifikasikan penyebab dari abnormalitas beragama. Pertama, adanya faktor internal. Penyebab internal ini bisa disebabkan adanya qalbu yang merupakan sentral kepribadian manusia mengalami sakit atau terintervensi oleh nafsu dan akal. Nafsu dan akal mendominasi pemikiran seseorang dan mengubah orientasi hidup tanpa disertai pengembangan aspek spiritual yang tepat. Adapun penyebab kedua adalah faktor eksternal, yaitu adanya godaan dari setan, sehingga melanggar aturan-aturan yang sudah digariskan oleh agamanya. Selain itu adapula sebagian orang yang melakukan kekerasan dalam beragama ataupun mengambil suatu keputusan untuk melakukan perbuatan yang melanggar aturan agama disebabkan oleh adanya pengalaman frustrasi seperti pengalaman yang traumatis, pelecehan, perasaan ketidakadilan seperti kondisi ekonomi yang tidak menentu dan pengalaman emosional

\footnotetext{
${ }^{15}$ Didin Fatihudin, Metode Penelitian (Sidoarjo: Zifatama Publisher, 2015). 45

${ }^{16}$ Ngainun Naim dan Achmad Sauqi, Pendidikan Multikultural : Konsep dan Aplikasi (Yogyakarta: Ar-Ruzz Media, 2017). 19

17 Tarmizi Abbas dan Ismail Suardi Wekke, "Yang Datang Setelah Hujan: Sains-Agama Penerang Kegelapan” (INA-Rxiv, 2019). 1

${ }^{18}$ Naim dan Sauqi, Pendidikan Multikultural : Konsep dan Aplikasi. 21

${ }^{19}$ Saifuddin, Psikologi Agama. 212
} 
seperti rasa marah, cemas dan sedih. ${ }^{20}$ Secara umum, hal tersebut pada dasarnya bisa ditelaah melalui pedekatan psikologis, sosiologis dan kultural.

\section{Pendekatan Psikologis Atas Prasangka dan Diskriminasi Dalam Beragama}

Terkait perilaku beragama seseorang yang ditampakkan dalam interaksi sosialnya sehari-hari bisa dikaji melalui beberapa pandangan. Salah satunya adalah melalui pandangan Psikonanalisis oleh Sigmund Freud, yang memamparkan bahwa seseorang saat dilahirkan memiliki komponen id, ego dan super ego. Id adalah dorongan-dorongan yang harus dipuaskan. Selanjutnya munculah super ego yang diyakini sebagai nilai-nilai luhur yang diterima seseorang dari lingkungannya. Antara id dan super ego inilah yang sering muncul pertentangan, yakni disaat id mewakili kepentingan pribadi dan super ego mewakili kepentingan masyarakat maka ego lah yang akan berperan diantara keduanya untuk memilih mana yang akan didahulukan. Ego akan memilih berdasarkan prioritas kebutuhan dan akan menentukan kapan dan bagaimana keinginan atau dorongan tersebut dipuaskan sesuai dengan tersedianya peluang yang resikonya minimal. ${ }^{21}$ Freud memaparkan bahwa agama dalam ciri-ciri psikologisnya adalah sebuah ilusi, yakni kepercayaan yang dasar utamanya adalah wishfullfillment. Manusia akan lari kepada agama oleh karena adanya rasa ketidakberdayaan menghadapi hal yang besar seperti bencana, takut mati, tidak ingin disiksa dan lain-lain. Artinya seseorang akan melakukan perilaku beragama semata-mata didorong oleh keinginan untuk menghindari keadaan bahaya yang akan menimpa dirinya dan memberi rasa aman bagi diri sendiri. Manusia sendirilah yang menciptakan keberadaan Tuhan dalam pikirannya, dan terkait tata cara penyembahan akan sangat dipengaruhi oleh bagaimana orang-orang terdahulu memberi contoh melakukannya. ${ }^{22}$

Melalui pandangan Behavioristik, Skinner memaparkan bahwa perilaku beragama, berprasangka, melakukan diskiriminasi ataupun kekerasan dapat dijelaskan berdasarkan teori pengkodisian operan (operant conditioning). Manusia pada dasarnya saat melakukan sesuatu dalam lingkungannya akan membawa pada akibat-akibat, baik itu untuk mendatangkan pemenuhan kebutuhan atau pengalaman yang tidak enak. Perilaku seseorang dalam beragama pada dasarnya merupakan ungkapan bagaimana manusia dengan pengkondisian operan belajaruntuk hidup di dunia yang dikuasai oleh hukuman jika melakukan kesalahan. ${ }^{23}$

Perilaku prasangka dan diskriminatif terjadi salah satunya disebabkan karena sikap-sikap yang dipelajari. Sikap-sikap ini bisa berasal dari apa yang dilihat, didengar atau internalisasi norma yang didapatkan dari lingkungan sosialnya. Sebagai contoh orang tua yang disiplin menjalankan ajaran agamanya akan diikuiti oleh anaknya untuk melakukan perilaku yang sama. ${ }^{24}$

Faktor pengalaman memiliki andil dalam hal dorongan untuk melakukan ritual agama. Kegiatan keagamaan akan diulangi karena berperan sebagai faktor penguat untuk meredakan ketegangan. Adanya keberadaan institusi agama merupakan sebuah lembaga yang bertugas untuk menjadi dan mempertahankan perilaku atau kebiasaan masyarakat. ${ }^{25}$

Dalam pandangan Maslow mengacu pada aliran Humanistik, perilaku seseorang didorong oleh adanya kebutuhan kebutuhan yang ada sejak lahir yang tersusun dalam suatu tingkatan dari yang paling rendah sampai dengan yang paling tinggi. Kebutuhan tersebut berawal dari kebutuhan

${ }^{20}$ Mirra Noor Milla, Mengapa Memilih Jalan Teror : Analisis Psikologis Pelaku Teror (Yogyakarta: Gadjah Mada University Press, 2010). 55-65

${ }^{21}$ Alwisol Alwisol, Psikologi Kepribadian (Malang: UMM Press, 2005). 20

${ }^{22}$ Djamaluddin Ancok dan Fuad Nashori Suroso, Psikologi Islami (Yogyakarta: Pustaka Pelajar, 2011). 70-71

${ }^{23}$ Bimo Walgito, Pengantar Psikologi Umum (Yogyakarta: CV. Andi Offset, 2010). 80-82 54-70.

${ }^{24}$ Triana Rosalina Noor, "Remaja dan Pemahaman Agama," Vicratina: Jurnal Pendidikan Islam 3, no. 2 (2019):

${ }^{25}$ Ancok dan Suroso, Psikologi Islami. 73 
fisiologis, kebutuhan rasa aman, kebutuhan rasa cinta, kebutuhan penghargaan dan kebutuhan aktualisasi diri. Kebutuhan tersebut tidak bergerak lurus, melainkan saling memuaskan manakala jika terdapat kebutuhan pada tingkat tertentu yang belum terpenuhi maka akan kembali ke jenjang tersebut untuk dipenuhi sampai memperoleh tingkat kepuasan yang dikehendaki. ${ }^{26}$ Terkait kebutuhan dalam konteks agama menempati posisi diatas dari kelima kebutuhan tersebut, yakni merupakan puncak dari kesempurnaan manusia. Pada posisi ini seseorang akan memiliki pengalaman-pengalaman puncak yang akan memberikan wawasan tentang dirinya dan dunia mereka. Kehidupannya akan lebih mistik, puitis dan saleh. ${ }^{27}$ Semua orang terdorong untuk meningkatkan passion keagamaannya seiring dengan perkembangan daya pikirnya dan rasa keagamaan akan berkembang seiring dengan pemahaman dan kondisi psikisnya. ${ }^{28}$

Secara umum, seseorang terdorong melakukan perilaku ketaatan ataupun melanggar aturan yang diterapkan oleh agamanya disebabkan adanya dorongan atau kebutuhan ataupun keinginan dari masing-masing individu. Kebutuhan tersebut yang pada nantinya akan mengarahkan seseorang untuk melakukan pada dalam kehidupan sosial. Artinya munculnya prasangka dan diskriminasi ini didorong oleh kebutuhan dari manusia itu sendiri karena merasa posisi dirinya sudah pada posisi yang sempurna daripada orang lain. Prasangka dikarenakan adanya keinginan untuk mengeksploitasi keberadaan golongan-golongan lain untuk kemajuan golongannya sendiri. ${ }^{29}$

\section{Pendekatan Sosiologis Atas Prasangka dan Diskriminasi Dalam Beragama}

Pendekatan sosial akan mencoba memaparkan bagaimana secara situasi dan kondisi lingkungan menstimulasi seseorang dalam berprasangka dan diskriminasi dalam beragama bahkan melakukan tindakan kekerasan, salah satunya dengan menggunakan pandangan teori atribusi. Atribusi merupakan upaya untuk mengetahui latar belakang seseorang dalam berperilaku dengan dikaitkan dengan lingkungan. Mengutip model proses atribusi dari Heider bahwa seseorang melakukan sesuatu dalam interaksi sehari-hari disebabkan oleh adanya kekuatan-kekuatan linkungan (environmental forces) atau kekuatan-kekuatan internal (termasuk disposisi). Kekuatankeuantan lingkungan tersebut adalah faktor situasi yang menekan sehingga memaksa untuk melakukan perilaku tertentu. Kekuatan-kekuatan internal tersebut seperti kemampuan, kekuatan dan usaha yang ditunjukkan oleh seseorang. ${ }^{30}$ Sebagai contoh adalah ada seorang wanita berjilbab yang berada di sebuah tempat yang penuh sesak sehingga ia mendorong-dorong orang lain. Menurut pendekatan atribusi ini, perilaku wanita berjilbab ini belum bisa langsung disimpulkan kalau dia adalah wanita yang kasar dan tidak bisa melakukan perbuatan yang pantas sehingga tidak tepat jika wanita tadi di judge wanita tidak sholehah.

Terkait dengan perilaku seseorang dalam interaksi sosial bisa juga dipaparkan melalui tindakan dengan mengkategorikan sebagai tindakan yang in group dan out group. W. G. Sumner memaparkan dalam proses sosial, seseorang akan memiliki konsep "kami" dengan "mereka". Sebuah kelompok yang mana individu tersebut mengidentifikasikan dirinya merupakan in group nya. Out group merupakan kelompok yang menjadi lawan dari "in group" nya. Proses in group dan out group ini ditentukan oleh situasi sosail. Artinya adalah akan ada istilah "kami atau kita" dan

\footnotetext{
${ }^{26}$ Alwisol, Psikologi Kepribadian. 255

${ }^{27}$ Ancok dan Suroso, Psikologi Islami. 75

28 Triana Rosalina Noor, "Mengembangkan Jiwa Keagamaan Anak (Perspektif Pendidikan Islam dan Perkembangan Anak Usia Dini)," KUTTAB 4, no. 2 (2020): 458.

${ }^{29}$ Gerungan, Psikologi Sosial, 188.

${ }^{30}$ Dayakisni dan Hudaniah, Psikologi Sosial. 39
} 
"mereka" ${ }^{31}$. Adanya perasaan in group sering menimbulkan "in group bias" yaitu kecenderungan untuk menganggap baik atas kelompoknya sendiri. In group bias merefleksikan perasaan-perasaan suka pada in group dan tidak suka pada out group. ${ }^{32}$ Adanya posisi sebagai anggota dari in group dan out group akan menimbulkan konsekuensi yakni : ${ }^{33}$

1. In group favoritism effect, yakni orang-orang yang berada pada in group akan mengevaluasi keanggotaanya secara lebih positif, memberi penilaian yang positif, lebih menghargai, memperlakukan dengan lebih baik dan menganggap keberadaan mereka lebih menarik daripada anggota out group. Artinya saat seseorang merasa menjadi anggota dari suatu kelompok maka dia kan cenderung menyukai sesama kelompoknya dan mejadi tidak suka pada anggota kelompok lain

2. Assumed similarity effect (efek kemiripan yang diasumsikan). Anggota yang berada pada in group memiliki banyak kesamaan dengan diri mereka sendiri. Artinya seseorang akan cederung merasa mirip atau memiripkan diri dengan sebuah kelompok yang sama dan tetap memandang sama anggota kelompok yang memiliki kesamaan dengan anggota lainnya dibandingkan dengan anggota kelompok yang berbeda.

3. Out group homogenity effect. Seseorang akan menganggap anggota yang ada dalam out group sebagai orang yang berbeda dari dirinya dan cenderung akan memandang mereka juga sebagai pribadi yang homogen dalam hal sifat, personalitas dan jumlah sub tipenya. Artinya akan muncul ungkapan "Mereka semua sama, sedangkan kita semua berbeda dengan mereka".

Adanya konsekuensi yang ditimbulkan khususnya In group favoritism effect adalah efek yang paling penting yang mempengaruhi cara seseorang untuk memperlakukan orang lain, akan merasa dirinya paling hebat sehingga akan mengganggap orang lain salah dan berbeda sehingga tidak perlu berinteraksi. In group nya akan menjadi kelompok yang akan digunakan sebagai alat ukur (standard) untuk menilai diri sendiri dalam menentukan sikap. ${ }^{34}$ Keberadaan perilaku dan perasaan in group seakan-akan menyatakan bahwa anggota dalam in group yang benar dan diluar itu salah dan tidak diperkenankan keberadaannya, dan pada akhirnya muncullah keinginan untuk berprasangka dan diskriminasi kepada orang lain.

Secara umum latar belakang seseorang dalam berperilaku seperti beragama, berprasangka, berperilaku diskriminatif bahkan sampai dengan perilaku kekerasan dipengaruhi oleh kekuatankekuatan yang ada di lingkungannya. Manusia akan merespon sesuatu dikarenakan adanya rangsangan dari luar dirinya. ${ }^{35}$ Perilaku, lingkungan dan individu saling berhubungan atau berinteraki satu sama lain bahkan saling mempengaruhi ${ }^{36}$.

\section{Pendekatan Sosiokultural Atas Atas Prasangka dan Diskriminasi Dalam Beragama}

Kebudayaan merupakan cetak biru bagi kehidupan atau pedoman bagi kehidupan masyarakat. Artinya adalah kebudayaan yang ada dalam suatu masyarakat akan dijadikan acuan bagi masyarakat/sebagian orang dalam berperilaku dalam interaksi.

\footnotetext{
${ }^{31}$ Soerjono Soekanto, Sosiologi Suatu Pengantar (Jakarta: PT. RajaGrafindo Persada, 2012). 134-135

${ }^{32}$ Dayakisni dan Hudaniah, Psikologi Sosial. 205

${ }^{33}$ Harmaini Harmaini et al., Psikologi Kelompok (Jakarta: PT. RajaGrafindo Persada, 2016). 92-94

34 Triana Rosalina Noor, "Orientasi Aktivitas Dan Kelompok Keagamaan Mahasiswa," in Prosiding Seminar Nasional Islam Moderat, vol. 1 (Jombang: Unwaha, 2018), 154-163.

${ }^{35}$ Sumadi Suryabrata, Psikologi Kepribadian (Jakarta: PT. RajaGrafindo Persada, 2013). 349

36 Triana Rosalina Noor, "Analisis Desain Fasilitas Umum Bagi Penyandang Disabilitas (Sebuah Analisis Psikologi Lingkungan),” Journal An-Nafs: Kajian Penelitian Psikologi 2, no. 2 (2017): 187-211.
} 
Seiring dengan majunya teknologi, membuat manusia semakin mudah dalam berhubungan. Kehidupan di era global seperti ini akan saling pengaruh mempengaruhi atas perilaku seseorang. Hasilnya adalah segala sesuatu yang sebelumnya tidak diakui sebagai budayanya akan terangkat menjadi suatu kebudayaan bersama. Hal yang dikhawatirkan adalah budaya-budaya yang saling mempengaruhi tersebut merupakan budaya yang justru akan membuat krisis kemanusiaan sehingga akan membawa pada suatu peradaban manusia yang menuju pada ketidakadilan. Diantaranya adalah adanya perubahan dalam sikap manusia. Melalui kebudayaan dan kepercayaan pada nilainilai yang dianut tersebutlah, seseorang akan mengamati keberadaan orang yang berbeda dengan dirinya. ${ }^{37} \mathrm{Hal}$ ini menyebabkan seseorang atau masyarakat menjadi mudah sekali untuk menilai orang lain hanya menurut persepsinya masing-masing. ${ }^{38}$

Artinya kebudayaan yang ada di sebuah masyarakat merupakan salah satu faktor yang dapat mempengaruhi sikap, nilai dan cara seseorang untuk menilai orang lain. Munculnya perilaku diskriminasi dan prasangka terjadi salah satunya marak karena peran media massa. ${ }^{39}$ Keberadaan media massa ini tidak terlepas dari bahasa sebagai media komunikasi manusia. Bahasa dan lingkungan sosiokultural memiliki hubungan timbal balik yang saling mempengaruhi manusia dalam berperilaku dalam bentuk budaya. Budaya tersebutlah yang akan mempengaruhi pembentukan identitas pada diri seseorang dan bisa jadi juga akan melakukan identity denial pada orang lain. ${ }^{40}$ Perilaku manusia dipengaruhi oleh adanya kebudayaan maupun sub kultur konteks. ${ }^{41}$

\section{Usaha-usaha Untuk Mencegah dan Mengurangi Prasangka dan Diskriminasi Dalam Beragama}

Menelisik konteks prasangka dan diskriminasi dalam beragama melalui beberapa pendekatan teoritik, maka akan dikemukakan beberapa hal untuk mencegah ataupun mengurangi timbulnya prasangka dan diskriminasi, yakni :

1. Upaya pencegahan prasangka dan diskriminasi

a. Meningkatkan nilai dari kelompok yang diprasangkai

Salah satu cara yang bisa diusahakan sebagai upaya pencegahan prasangka dan diskriminasi adalah dengan cara meningkatkan nilai dari kelompok yang distigmatisasi oleh kelompok lain. Maksudnya adalah kelompok lain yang berbeda dengannya itu sebenarnya juga memiliki nilai dan hal yang bisa dihargai oleh orang lain. Ini berfungsi agar terwujudnya kesadaran dari sebuah kelompok yang diprasangkai tersebut pada dasarnya memiliki kompetensi dan kemampuan sebagaimana kelompok yang menghujat. Hal ini bisa sebagai langkah awal dalam upaya menghargai keberadaan orang lain.

Menghargai keberadaan orang lain merupakan salah satu bentuk toleransi. Toleransi merupakan sebuah perilaku yang ditunjukkan dengan meghormati sifa dasar, keyakinan dan perilaku yang ditampakkan oleh orang lain. ${ }^{42}$

b. Membuat perbandingan dalam kelompok

Sebagai usaha mencegah terjadinya prasangka dan diskriminasi, melakukan proses perbandingan nilai secara internal dalam sebuah kelompok merupakan hal yang bijak. Maksudnya adalah sebelum berprasangka dan mendiskriminasikan orang lain, ada baiknya membandingkan hal yang dijadikan bahan perbandingan ditujukan ke dirinya terlebih

\footnotetext{
${ }^{37}$ Triana Rosalina Noor, "Pendidikan Islam Sebagai Sebuah Sistem Di Era 4 . 0” 2, no. 2 (2019): 19.

${ }^{38}$ Jalaluddin Jalaluddin, Psikologi Agama (Jakarta: PT. RajaGrafindo Persada, 2012). 226-234

${ }^{39}$ Dayakisni dan Hudaniah, Psikologi Sosial. 209

${ }^{40}$ Sarlito W. Sarwono, Psikologi Lintas Budaya (Jakarta: PT. RajaGrafindo Persada, 2015). 69-73

${ }^{41}$ Alo Liliweri, Prasangka dan Konflik: Komunikasi Lintas Budaya Masyarakat Multikultur (Yogyakarta: LKiS,

${ }^{42}$ Naim dan Sauqi, Pendidikan Multikultural : Konsep dan Aplikasi. 77
} 2005). 361 
dahulu. Hal ini sebagai wujud usaha meredam niatan untuk melakukan diskriminasi terhadap orang lain.

Melakukan proses memilah-milah sebuah persepsi dan nilai-nilai mana saja yang patut dilakukan akan sangat membantu seseorang untuk melakukan persepsi yang tepat atas lingkungannya. Melakukan perubahan atas persepsi-persepsi yang dimiliki akan sangat bermanfaat dikarenakan persepsi-persepsi inilah yang akan mengarahkan sebuah perilaku dan tindakan yang dilakukan pada nantinya. ${ }^{43}$

c. Mengkondisikan lingkungan

Mengkondisikan lingkungan bisa dijadikan sebagai alternatif cara dalam meredam dan meminimalkan terjadinya prasangka dan perilaku diskriminasi. Hal ini bisa dilakukan dengan cara mengatur agar seseorang tidak melakukan suatu hal yang menyulut terjadi penilaian ekstrim dari kelompok lain. Sebagai contoh seseorang diarahkan untuk melakukan perubahan dalam sikap atau hidup, menyesuaikan cara berpakaian atau beradaptasi cepat dengan lingkungan agar meminimalkan kemungkinan prasangka terjadi.

Pada sebuah masyarakat yang memaknai agama sebagai pemaknaan dalam sistem nilai, maka akan muncul simbol-simbol budaya yang dipinjam disana. Agama akan mengalami penyesuaian dengan kebudayaan yang berlaku dimasyarakatnya. Ada kompromi nilai atau simbol yang masuk ke budaya asal yang menghasilkan bentuk baru dan berbeda dengan bentuk asalnya. Proses penyesuaian ini terjadi begitu saja dalam setiap proses pemaknaan dalam suatu masyarakat yang telah memiliki struktur kebudayaan. ${ }^{44}$

2. Upaya penanggulangan prasangka dan diskriminasi

a. Membuka komunikasi antar kelompok yang berprasangka

Adanya komunikasi antar kelompok yang berprasangka melalui mediasi pihak ketiga diharapkan bisa menyelesaikan konflik prasangka yang telah terjadi. Hanya saja peran emosional juga dilibatkan agar hasil mediasi yang telah dilakukan bukan hanya sebagai suatu formalitas belaka.

Pada konteks prasangka dalam beragama, adanya suatu komunikasi atau dialog antar agama bisa menjadi sebuah alternatif yang dipilih. Hal ini dikarenakan komunikasi antar agama penting dilakukan untuk menghindari perdebatan teologis antar pemeluk agama. Pesan-pesan agama yang sudah diinterpretasikan selaras secara universal akan menjadi modal terciptanya dialog yang harmonis. Melalui dialog antar agama akan memberikan hak setiap orang untuk mengamalkan keyakinannya dan menyampaikannya kepada orang lain. ${ }^{45}$ Menerima keberadaan orang lain tidak dengan menggunakan persepsi agama yang dianutnya akan menjadi penguat kerukunan dan meminimalisir konflik. ${ }^{46}$

b. Personalisasi anggota out group

Melakukan proses humanisasi pada kelompok yang dianggap out group menjadi penting untuk dilakukan mengatasi prasangka. "Memanusiakan" anggota yang dianggap out group bukan berarti harus memahami semua kebutuhan dari anggota out group tersebut,

\footnotetext{
${ }^{43}$ Ahmad Dzikran, Jadilah Diri Sendiri: Panduan Membangun Pribadi Berkarakter Dan Percaya Diri (Pustaka Alvabet, 2018). 9-10

${ }^{44}$ Dadang Kahmad, Sosiologi Agama (Potret Agama dalam Dinamika Konflik, Pluralisme dan Moderenitas) (Bandung: CV. Pustaka Setia, 2011). 20-22

${ }^{45}$ Ibid. 160

46 Tualeka, Sosiologi Agama. 160
} 
melainkan sebagai wujud penghormatan, menjunjung rasa kemanusiaan dan menunjukkan empati.

Pada dasarnya kehadiran agama bertujuan untuk memanusiakan manusia, agar bisa mengoptimalkan segala potensi yang dimiliki. Artinya dalam berinteraksi sosial, seseorang akan diminta untuk memenuhi hak dan kewajibannya terhadap sesama dan pada akhirnya kesemuanya itu akan dipertanggungjawabkan kepada Allah SWT. Manusia harus bisa hidup bersama dalam interaksi dan interdependensi dengan sesamanya, karena pada dasarnya manusia itu meMbutuhkan keberadaan orang lain. ${ }^{47}$

c. Penguatan norma sosial

Pada proses minimalisasI prasangka, penegakan norma sosial menjadi penting untuk dilakukan. Norma sosial yang ada di masyarakat akan mencegah perilaku diskriminasi oleh karena norma sosial tersebut merupakan sebuah kesepakatan dari banyak pihak yang menginginkan sebuah komunitas yang damai.

Norma sosial pada dasarnya sama dengan norma kelompok. Norma sosial merupakan hasil dari bermacam-macam interaksi kelompok yang mana didalamnya mencakup nilai sosial, adat istiadat, tradisi, kebiasaan, konvensi dan lain sebagainya. Norma sosial tersebut akan menjadi patokan terkait tingkah laku dan sikap individu yang dikehendaki oleh kelompok tersebut. Artinya norma sosial harus dipatuhi mengingat norma sosial dibuat berdasarkan hubungan timbal balik antar individu-individu yang menjadi anggota kelompok sosial ${ }^{48}$.

\section{Menuju Masyarakat Indonesia Yang Multikultural, Bebas Prasangka dan Diskriminasi}

Suatu kenyataan historis bahwa Indonesia merupakan bangsa yang hidup dalam kebhinekaan (pluralitas), termasuk didalamnya kebhinekaan paham keagamaan interumat beragama. Pengakuan pada pluralitas agama tersebut semakin dikukuhkan melalui era reformasi yang mendorong semakin demokratisnya dan terbukanya sikap keberagamaan. Era reformasi memberi angin segar kepada kehidupan sosial keberagamaan di Indonesia, dimana setiap penganut agama yang diakui di Indonesia diberi kesempatan untuk berekspresi.

Telah diketahui bahwa permasalahan bangsa Indonesia adalah masyarakatnya sangat mudah tersulut konflik-konflik sosial yang bernuansa SARA (suku, agama, ras dan antar golongan) sebagaimana pengalaman-pengalaman sebelumnya. Masyarakat Indonesia memiliki kondisi kultural, sosial dan geografis yang beragam, sehingga dibutuhkan usaha dari masing-masing elemen bangsa untuk menjaga keutuhan bangsa dan negara. Apalagi prasangka dan diskriminasi tersebut sangat mudah tersulut manakala terdapat persaingan dalam memperebutkan sumber daya di masingmasing daerahnya. ${ }^{49}$

Mengacu pada kondisi masyarakat Indonesia tersebut maka terbentukah suatu nilai terkait masyarakat multikultural. Pembentukan masyarakat multikultural yang ada di Indonesia berlandaskan pada azas Bhineka Tunggal Ika, yang berimplikasi pada keinginan bersama yakni mewujudkan suau kultur nasional yang menjadi pemersatu masyarakat Indonesia. Masyarakat multikutural dapat dipahami sebagai sebuah pengakuan kalau keberagamaan di masyarakat itu merupakan suatu keniscayaan. Adanya perbedaan terhadap suatu kebudayaan atau kehidupan masyarakat yang berbeda antara satu dengan yang lain merupakan suatu realitas yang harus

\footnotetext{
${ }^{47}$ Jalaluddin Jalaluddin dan Abdullah Idi, Filsafat Pendidikan : Manusia, Filsafat dan Pendidikan (Jakarta: PT. RajaGrafindo Persada, 2014). 134-135

${ }^{48}$ Gerungan, Psikologi Sosial. 110-113

${ }^{49}$ Fuad Nashori, Psikologi Sosial Islami (Bandung: PT. Refika Aditama, 2008), 88.
} 
diterima. ${ }^{50}$ Perbedaan tersebut dibiarkan secara alami apa adanya dan akan menjadi ciri khas penanda yang akan membuat sebuah keunggulan dalam sebuah negara. ${ }^{51}$

Masyarakat Indonesia akan menciptakan masyarakat multikultural yang sebenarnya adalah manakala setiap warganya saling hidup berdampingan, saling toleran, saling menghormati dan saling menghargai. Hidup berdampingan dalam suasana yang damai ini penting karena persoalan akan muncul manakala masyarakat mengingkari dan ingin memusnahkan perbedaan yang ada tadi sehingga akan mengganggu masa depan multikulturalisme Indonesia. Terlebih jika konflik tersebut yang disebabkan oleh keberagaman melebar pada sebuah perebutan panggung politik, ideologi dan harga diri yang malah akan melemahkan toleransi yang telah ada. Oleh karenanya dibutuhkan penyelesaian konflik yang konstruktif guna menyelesaikan permasalahan yang terjadi melalui tata perencanaan yang tepat. ${ }^{52}$

Mudahnya keberagaman dibawa pada suatu konflik atau multikulturalisme yang digaungkan selama ini dipandang dengan sebelah mata oleh sebagian orang adalah hal yang bisa dipahami, khususnya saat menoleh pada pengalaman pahit kehidupan beragama di Indonesia pada zaman orde baru. Multikulturalisme di Indonesia dianggap oleh sebagian orang sebagai sikap egois atau lemahnya keimanan kepada Tuhan YME oleh masing-masing penganut agama. Oleh karena itu usaha mewujudkan multikulturalisme di Indonesia membutuhkan usaha dari semua pihak. Multikulturalisme harus dibentuk dan dibangun berdasarkan kesamaan tujuan dari semua warganya, agar tidak ada lagi prasangka, kebencian, membeda-bedakan dan merasa dirinya paling benar. ${ }^{53}$ Para elemen dari bangsa ini harus memiliki pemahaman yang sama bahwa keberagaman dan multikultural yang ada memang merupakan desain, anugerah dan rahmat dari Allah SWT, sebagaimana Alah SWT berfirman pada Surat Al-Hujurat ayat 13. Pada ayat tersebut membawa makna timbal balik bahwa ada makna kata lita'arafu sebagai saling mengenal dan menjelaskan bahwa manusia secara fitrah memang sudah memiliki naluri untuk berkelompok dan berkabilah, dan fenomena kabilah tersebut merupakan sunatullah yang tidak mungkin dihindari. ${ }^{54}$ Oleh karena itu antara individu-individu dalam suatu masyarakat diharapkan untuk memupuk sikap saling memahami dan menghormati perbedaan yang ada sehingga tidak terjadinya kebuntuan komunikasi yang berakibat pada perselisihan, konflik, dan kehancuran. ${ }^{55}$ Tujuan akhirnya adalah tumbuhnya semangat nasionalisme dan menderadikalisai paham radikal sebagai wujud pelestarian Islam rahmatan lil alamin dalam memperkokoh persatuan bangsa Indonesia. ${ }^{56}$

\section{Kesimpulan dan Saran}

Prasangka dan diskriminasi khususnya pada konteks keagamaan adalah perilaku yang akan mengancam keutuhan bangsa Indonesia sebagai bangsa yang multikultiral. Perilaku prasangka dan diskriminasi tersebut terbentuk dalam diri seseorang dikarenakan adanya faktor psikologis individual, sosiologis dan kultural. Prasangka beragama akan memicu terjadinya diskriminasi dan tindak kekerasan dalam lingkungan masyarakat. Jika perilaku ini berlangsung terus menerus maka

\footnotetext{
${ }^{50}$ Hasan, Pendidikan Multikultural Sebagai Opsi Penanggulangan Radikalisme. 143

51 Ardhana Januar Mahardhani dan Hadi Cahyono, "Harmoni Masyarakat Tradisi Dalam kerangka Multikulturalisme,” ASKETIK: Jurnal Agama dan Perubahan Sosial 1, no. 1 (2017). 27

${ }^{52}$ Triana Rosalina Noor, "Alternatif Pemecahan Masalah Pada Masyarakat Multikultural," Al Iman: Jurnal Keislaman dan Kemasyarakatan 4, no. 2 (2020): 231.

${ }^{53}$ Choirul Mahfud, Pendidikan Multikultural (Yogyakarta: Pustaka Pelajar, 2016). 103-106

${ }^{54}$ Kahmad, Sosiologi Agama (Potret Agama dalam Dinamika Konflik, Pluralisme dan Moderenitas). 174-175

${ }_{55}$ Mukti Ali, Harmoniv Harmonical Communication : Sebuah Pesan Damai dalam Perbedaan (Salatiga: LP2MPress, Institut Agama Islam Negeri (IAIN) Salatiga, 2016), http://e-repository.perpus.iainsalatiga.ac.id/1805/. 173

${ }^{56}$ Subandi Subandi, "Manajemen Pendidikan Multikultur Dan Aktualisasi Islam Moderat Dalam Memperkokoh Nasionalisme Di Indonesia,” Fikri: Jurnal Kajian Agama, Sosial dan Budaya 3, no. 2 (2018): 301-312.
} 
tidak menutup kemungkinan semangat multikulturalisme yang diharapkan akan menguap dengan sendirinya. Pencegahan prasangka dan perilaku diskriminasi dalam beragama ini bisa dilakukan dengan cara meningkatkan nilai dari kelompok yang diprasangkai, membuka komunikasi, mengkondisikan liingkungan sampai dengan internalisasi norma sosial. Harapannya terwujudnya sikap saling menghargai, saling menghormati, saling tolong menolong, toleransi dan semangat hidup berdampingan.

Oleh karena itu, pada dasarnya multikulturalisme itu bukan hanya konsep yang ada di langit, tapi harus dibumikan sebagai solusi atas permasalahan sosial yang terjadi di masyarakat Indonesia. Penerapan multikulturalisme juga harus melibatkan komitmen dari masing-masing elemen dalam menyikapi dinamika keberagaman, perubahan dan konflik agar menuju masa depan kehidupan bangsa yang lebih damai, sejahtera dan berkeadilan.

\section{E. Daftar Pustaka}

Abbas, Tarmizi, dan Ismail Suardi Wekke. "Yang Datang Setelah Hujan: Sains-Agama Penerang Kegelapan,” 2019.

Akhmad, Harits Tryan. "FPI Minta Mahfud MD Bersuara Lantang soal Dugaan Kriminalisasi Ulama dan Diskriminasi Hukum." Last modified 2020. https://nasional.sindonews.com/read/250890/13/fpi-minta-mahfud-md-bersuara-lantang-soaldugaan-kriminalisasi-ulama-dan-diskriminasi-hukum-1606720276.

Ali, Mukti. Harmoniv Harmonical Communication: Sebuah Pesan Damai dalam Perbedaan. Salatiga: LP2M-Press, Institut Agama Islam Negeri (IAIN) Salatiga, 2016. http://erepository.perpus.iainsalatiga.ac.id/1805/.

Alwisol, Alwisol. Psikologi Kepribadian. Malang: UMM Press, 2005.

Amrullah, Sony. "Melacak Jejak Radikalisme dalam Islam: Akar Ideologis dan Eksistensinya dari Masa ke Masa." Dirasah: Jurnal Studi Ilmu dan Manajemen Pendidikan Islam 1, no. 2 (2018): $1-9$.

Ancok, Djamaluddin, dan Fuad Nashori Suroso. Psikologi Islami. Yogyakarta: Pustaka Pelajar, 2011.

Bordens, Kenneth S., dan Irwin A. Horowitz. Social Psychology. USA: Freeload Press, 2008.

Dayakisni, Tri, dan Hudaniah Hudaniah. Psikologi Sosial. Malang: UMM Press, 2012.

Dzikran, Ahmad. Jadilah Diri Sendiri: Panduan Membangun Pribadi Berkarakter Dan Percaya Diri. Pustaka Alvabet, 2018.

Fatihudin, Didin. Metode Penelitian. Sidoarjo: Zifatama Publisher, 2015.

Gerungan, W. A. Psikologi Sosial. Bandung: PT. Refika Aditama, 2004.

Harmaini, Harmaini, Dede Fitriana Anastasia, Ivan Muhammad Agung, dan Ricca Angreini Munthe. Psikologi Kelompok. Jakarta: PT. RajaGrafindo Persada, 2016.

Harto, Kasinyo. Model Pengembangan Pendidikan Agama Islam Berbasis Multikultural. Jakarta: PT. RajaGrafindo Persada, 2014.

Hasan, Muhammad Tholchah. Pendidikan Multikultural Sebagai Opsi Penanggulangan Radikalisme. Malang: Lembaga Penerbitan Univ. Islam Malang, 2016.

Jalaluddin, Jalaluddin. Psikologi Agama. Jakarta: PT. RajaGrafindo Persada, 2012.

Jalaluddin, Jalaluddin, dan Abdullah Idi. Filsafat Pendidikan: Manusia, Filsafat dan Pendidikan. Jakarta: PT. RajaGrafindo Persada, 2014.

Kahmad, Dadang. Sosiologi Agama (Potret Agama dalam Dinamika Konflik, Pluralisme dan Moderenitas). Bandung: CV. Pustaka Setia, 2011. 
Kikooma, Julius F. "Using Qualitative Data Analysis Software in a Social Constructionist Study of Entrepreneurship." Qualitative Research Journal 10, no. 1 (2010): 40-51.

Liliweri, Alo. Prasangka dan Konflik: Komunikasi Lintas Budaya Masyarakat Multikultur. Yogyakarta: LKiS, 2005.

Mahardhani, Ardhana Januar, dan Hadi Cahyono. "Harmoni Masyarakat Tradisi Dalam kerangka Multikulturalisme." ASKETIK: Jurnal Agama dan Perubahan Sosial 1, no. 1 (2017).

Mahfud, Choirul. Pendidikan Multikultural. Yogyakarta: Pustaka Pelajar, 2016.

Milla, Mirra Noor. Mengapa Memilih Jalan Teror : Analisis Psikologis Pelaku Teror. Yogyakarta: Gadjah Mada University Press, 2010.

Naim, Ngainun, dan Achmad Sauqi. Pendidikan Multikultural : Konsep dan Aplikasi. Yogyakarta: Ar-Ruzz Media, 2017.

Nashori, Fuad. Psikologi Sosial Islami. Bandung: PT. Refika Aditama, 2008.

Noor, Triana Rosalina. "Alternatif Pemecahan Masalah Pada Masyarakat Multikultural." Al Iman: Jurnal Keislaman dan Kemasyarakatan 4, no. 2 (2020): 204-232.

"Analisis Desain Fasilitas Umum Bagi Penyandang Disabilitas (Sebuah Analisis Psikologi Lingkungan).” Journal An-Nafs: Kajian Penelitian Psikologi 2, no. 2 (2017): 187-211.

- "Meneropong Indonesia: Sebuah Analisis Sosiologis dan Psikologis Atas Konflik Benuansa Keagamaan Di Indonesia." Journal An-Nafs: Kajian Penelitian Psikologi 3, no. 2 (2018): 135-150.

_. "Mengembangkan Jiwa Keagamaan Anak (Perspektif Pendidikan Islam dan Perkembangan Anak Usia Dini).” KUTTAB 4, no. 2 (2020).

—. "Orientasi Aktivitas Dan Kelompok Keagamaan Mahasiswa." In Prosiding Seminar Nasional Islam Moderat, 1:154-163. Jombang: Unwaha, 2018.

—. "Pendidikan Islam Sebagai Sebuah Sistem Di Era 4 . 0" 2, no. 2 (2019): 18-36.

. "Remaja dan Pemahaman Agama." Vicratina: Jurnal Pendidikan Islam 3, no. 2 (2019): 54-70.

Saifuddin, Ahmad. Psikologi Agama. Jakarta: Kencana, 2020.

Saihu, Saihu. "Pendidikan Pluralisme Agama: Kajian tentang Integrasi Budaya dan Agama dalam Menyelesaikan Konflik Sosial Kontemporer.” Jurnal Indo Islamika 9, no. 1 (2019): 67-90.

Sarwono, Sarlito W. Psikologi Lintas Budaya. Jakarta: PT. RajaGrafindo Persada, 2015.

Soekanto, Soerjono. Sosiologi Suatu Pengantar. Jakarta: PT. RajaGrafindo Persada, 2012.

Subandi, Subandi. "Manajemen Pendidikan Multikultur Dan Aktualisasi Islam Moderat Dalam Memperkokoh Nasionalisme Di Indonesia." Fikri: Jurnal Kajian Agama, Sosial dan Budaya 3, no. 2 (2018): 301-312.

Sudarto, Sudarto. Wacana Islam Progresif. Yogyakarta: IRCiSod, 2014.

Suryabrata, Sumadi. Psikologi Kepribadian. Jakarta: PT. RajaGrafindo Persada, 2013.

Sutari, Tiara. "Selesaikan Konflik Masjid di Papua Lewat Musyawarah." Last modified 2018. https://www.cnnindonesia.com/nasional/20180318101351-20-283902/menag-selesaikankonflik-masjid-di-papua-lewat-musyawarah.

Tualeka, Hamzah. Sosiologi Agama. Surabaya: IAIN Sunan Ampel Press, 2011.

Walgito, Bimo. Pengantar Psikologi Umum. Yogyakarta: CV. Andi Offset, 2010.

"Diusir dari desa karena agama, bagaimana mencegah intoleransi di tingkat warga?" 2018. https://www.bbc.com/indonesia/indonesia-47801818. 